\title{
Yenilikçi teknolojilerden prensip ve yasal yönleriyle vurgulu elektrik alan teknolojisi
}

\section{Principles and legal issues of pulsed electric field technology as a novel technique}

\author{
Elif Ayşe ANLI ${ }^{* 1}$ iD \\ ${ }^{1}$ Ankara Üniversitesi Ziraat Fakültesi Süt Teknolojisi Bölümü, Ankara, Türkiye
}

\section{To cite this article:}

Anlı, E.A. (2019). Yenilikçi teknolojilerden prensip ve yasal yönleriyle vurgulu elektrik alan teknolojisi. Harran Tarım ve Gıda Bilimleri Dergisi, 23(3): 354363.

DOI: 10.29050/harranziraat.469870

\section{Address for Correspondence: Elif Ayşe ANLI \\ e-mail: \\ kocaoglu@agri.ankara.edu.tr, elifaysekocaoglu@gmail.com}

\section{Received Date:}

12.10.2018

Accepted Date:

09.05.2019

(C) Copyright 2018 by Harran University Faculty of Agriculture. Available on-line at www.dergipark.gov.tr/harranziraat
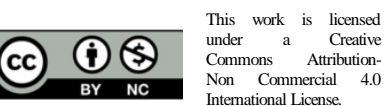

\section{öz}

Vurgulu elektrik alan (VEA) teknolojisi, gıdaların mikrobiyolojik kalitesinin iyileştirilmesini amaçlayan, beslenme yönünden özelliklerini koruyan aynı zamanda gıdaların fonksiyonel özelliklerinin geliştirilmesine katkı sağladığı bilinen bir tekniktir. Klasik ısıl işlem uygulamalarına kıyasla düşük sıcaklıklarda kısa süreli olarak gıdaya gönderilen elektrik alan sinyalleri ile bakteri sporları haricinde neredeyse tüm patojenler ve gıdalarda bozulma etmeni olan bakteriler inaktif hale getirilmektedir. VEA teknolojisi ile mikroorganizma inaktivasyon mekanizma üzerine, elektrik alan etkisiyle hücrelerde membran geçirgenliğinin artması, elektroporasyon sonucunda membranın gözenekli hale gelmesi ve yine aynı etkiyle oksidasyon ve redüksiyon reaksiyonlarının meydana gelmesi gibi mevcut görüşler bulunmaktadır. Yenilikçi teknolojilerden birisi olarak yöntemin güvenilirliği, yöntemin mikroorganizmalar üzerindeki başarısı ile birlikte toksikolojik ve alerjik etkileri yönünden desteklenerek, yasal otoriteler tarafından onaylandıktan sonra daha net olarak ortaya konulacaktır. Yöntemin ticari olarak uygulanabilirliğinin ülkelere göre değişiklik göstermeyen, global bir yasal düzenleme yapıldıktan sonra mümkün olacağı düşünülmektedir.

Anahtar Kelimeler: Vurgulu elektrik alan, Mikrobiyel inaktivasyon mekanizması, Uygulama alanları, Yasal düzenlemeler

\section{ABSTRACT}

The goal of Pulsed Electric Field (PEF) technology is to enhance microbiological properties of foods by protecting nutritional quality and also known as a technique contributing some functional properties of foods. Electric field signals applied at low temperatures for a short period of time results in inactivation of all pathogens and food deteriorating bacteria except bacterial spores. Improvement in cell permeability, electroporation in cell membrane and oxidation and reduction reactions occurring as a result of electric field are some theories about the microbial inactivation mechanism. As a novel technique the reliability of pulsed electric field, succeed in microbial inactivation, will be proved well when toxicological and allergenic effects are examined and confirmed positively and after legal authorities' approval. The technique's industrial application will be possible when global legal aspects are performed without variations according to countries.

Key Words: Pulsed electric field, Microbial inactivation mechanism, Application areas, Legal issues

\section{Giriş}

Gıdaların mikrobiyel açıdan güvenli hale getirilmesi, ticari olarak pastörizasyon ve sterilizasyon işlemleri yardımıyla gerçekleştirilmektedir. Ancak, bu uygulamaların protein denatürasyonu, enzimatik olmayan esmerleşme reaksiyonu, vitaminler ve uçucu bileşenlerin kaybı gibi istenmeyen bazı değişimlere yol açabildiği bilinmektedir (Corbo ve 
ark., 2009; Cullen ve ark., 2012, Buniowska ve ark., 2017; Gabrić ve ark., 2018). Bu nedenle, gıdaların besleyici, fonksiyonel ve duyusal özelliklerinde fazla bir değişim yaratmaksızın mikrobiyel kalitesi ve güvenilirliğini artıran yeni tekniklere karşı dünya genelinde artan bir ilgi duyulmaktadır (Wan ve ark., 2009). "Isıl olmayan" ya da "Isıl işleme alternatif" yöntemler olarak adlandırılan bu tekniklerin ısıl uygulamalara göre üstünlükleri, bozulma etmeni olan mikroorganizmaların ve enzimlerin inaktivasyonunun genellikle düşük sıcaklıkta gerçekleştirilmesi ile gıdaların biyolojik ve duyusal özelliklerinin optimum düzeyde korunmasının sağlanmasıdır (Vega-Mercado ve ark., 1997; Wan ve ark., 2009).

Yüksek hidrostatik basınç, yüksek güçlü ultrasonik ses dalgası, vurgulu ultraviyole ışı, vurgulu elektrik alan ve düşük sıcaklıkta plazma uygulamaları ısıl işleme alternatif olarak geliştirilen yeni teknikler arasındadır (Wan ve ark., 2009; Anonim, 2011b; Impe ve ark., 2018). $\mathrm{Bu}$ tekniklerden vurgulu elektrik alan (VEA) teknolojisi, sıvı ya da pompalanabilir özellikteki gıdalara uygulanabilen gelecek vaat eden bir teknolojidir. VEA uygulamasında yüksek yoğunluklu elektrik alan sinyalleri kullanılarak, oda sıcaklığının altında ya da oda sıcaklığına yakın bir sıcaklıkta çok kısa sürede mikrobiyel ve enzimatik inaktivasyon gerçekleştirilmektedir (Wan ve ark., 2009; Anonim, 2011b).

Gıdalarda elektrik akımı uygulamasına 1920'li yıllarda başlanmış, 1960'lı yıllarda simüle gıda sistemlerinde değişik mikroorganizmaların yok edilmesi amacıyla yararlanılmıştır. 1980 ve 90'lı yıllarda, VEA teknolojisinin, meyve suyu, çorba, çırpılmış yumurta ve yağsız süt gibi çeşitli sıvı gıdaların ve içeceklerin üretiminde başarılı bir şekilde kullanılabileceği görülmüştür (VegaMercado ve ark., 1997). Bu derlemede, VEA teknolojisinin prensibi, sistem donanımları, VEA tekniği ile mikrobiyel inaktivasyon mekanizması ve inaktivasyonu etkileyen faktörler ile VEA uygulamasının yasal yönleri konularında bilgi verilmeye çalışılacaktır.

\section{VEA Teknolojisi}

\section{Prensibi ve sistem parçaları}

VEA tekniği, elektrik alan uygulamasıyla, gıdanın yapısında bulunan ve belirli düzeyde elektrik iletimini sağlayan çok sayıdaki iyon tarafından, elektrik akımının, gıdanın her noktasına iletilmesi esasına dayanmaktadır (Anonim, 2011a). Böylece, elektriksel alanın yoğunluğuna bağlı olarak kritik eşik değerinin üzerinde, bakteri hücre zarında lokal olarak, geri dönüşümlü ya da geri dönüşümsüz yapısal değişimler meydana gelmektedir. Elektriksel alan etkisiyle hücre zarının geçirgenliğinde meydana gelen değişim Şekil 1'de gösterilmiştir.

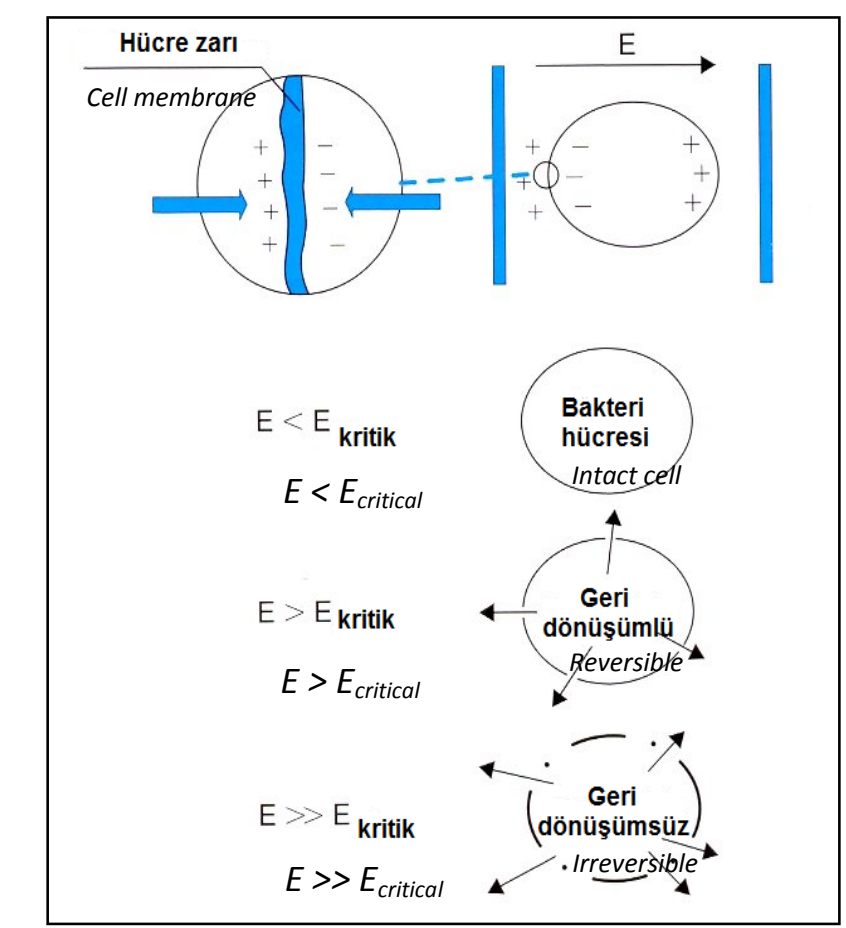

Şekil 1. Elektriksel alan etkisiyle hücre zarının geçirgenliğindeki değişim (Toepfl ve ark., 2005). (E: elektrik alan şiddeti)

Figure 1. Change in cell permeability by electric field (Toepfl ve ark., 2005). (E: electric field strength)

Bir VEA ünitesi, işlem haznesi, yüksek voltaj sinyal (sinyal) jeneratörü, sıvı taşıma sistemi ile kontrol ve görüntüleme araçlarından oluşmaktadır (Toepfl ve ark., 2005). İşlem haznesinde, iki elektrot arasına yerleştirilen gıdaya, genellikle oda sıcaklığında, 1-100 $\mu \mathrm{s}$ süreyle, elektrik alan şiddeti $10-80 \mathrm{kV} \mathrm{cm}^{-1}$ arasında değişen sinyaller gönderilmektedir (Schilling ve ark., 2007; Corbo ve ark., 2009; Anonim, 2011a., Gabrić ve ark., 2018). VEA 
uygulamasında deşarj süresinin mikrosaniye veya nanosaniye kadar kısa olması nedeniyle, gıdalar en az düzeyde ısının etkisine maruz kalmaktadır (Corbo ve ark., 2009). İşlemin düşük sıcaklıkta gerçekleştirilmesi sistemin enerji tüketimini de azaltmaktadır (Vega-Mercado ve ark., 1997; Wan ve ark., 2009).

\section{VEA Tekniği ile Mikroorganizmaların Inaktivasyonu}

\section{Inaktivasyon mekanizması}

Mikroorganizmalar hücre yapılarında ya da fizyolojik özelliklerinde değişime neden olan işlemlere maruz kaldıklarında inaktif hale gelmektedir. DNA zincirinin kırılması, hücre zarının parçalanması ya da hücre zarfının mekanik olarak hasar görmesi mikroorganizmalarda meydana gelen yapısal bozulmalara örnek olarak verilebilir. Önemli enzimlerin inaktif hale gelmesi ya da membran seçiciliğinin değişmesi ise hücre fonksiyonlarında değişim yaratan durumlardır. Isıl işlem uygulamaları, her iki mekanizma üzerinde etkili olmakta ve dolayısı ile hücre ölümüne neden olmaktadır (Lado ve Yousef, 2002).

VEA tekniği ile mikroorganizmaların inaktivasyon mekanizması henüz tam olarak aydınlanmamış olmakla birlikte, yüksek voltajlı elektrik alan etkisine maruz kalan hücrelerde membran geçirgenliğinin arttığı ve membranın yapısal ve fonksiyonel özelliklerinde meydana gelen değişimin hücre ölümüne neden olduğu ifade edilmektedir (Lado ve Yousef, 2002; Picart ve ark., 2002). Ayrıca VEA işleminin, hücre içerisinde oksidasyon ve redüksiyon reaksiyonlarını teşvik ettiği de belirtilmektedir (Vega-Mercado ve ark., 1997). Ayrıca bu konuda öne sürülen diğer bir görüşe göre; hücre membranının dışında zıt yüklü bileşiklerin birikmesinin membran üzerinde bir basınç yarattığı ve basıncın etkisiyle membranın kalınlığının azaldığı, membranda gözenekler oluşmasına bağlı olarak da hücre dışında biriken maddelerin membranlar arasındaki geçiş potansiyelini geçici olarak artırdığı yönündedir (Lado ve Yousef, 2002; Aronsson ve ark., 2005). VEA işlemi etkisiyle membran geçirgenliğinde artış meydana geldiğini, hücrelerde floresan özellik gösteren propidium iyot $(\mathrm{PI})$ boyasının hücre içine alımındaki artış ile belirlemişlerdir. Diğer bir görüş ise; VEA etkisiyle hücre membranın da meydana gelen elektroporasyondur. Bu görüşe göre; hedef hücrelere kritik trans-membran eşik değeri olan 1 V'dan daha yüksek elektrik alan şiddeti uygulanmasıyla, hücre zarında geri dönüşümsüz gözenekler oluşmakta ve yarı-geçirgen özellikteki hücre zarı zarar görmektedir (Wan ve ark., 2009). Protein kanallarında ve lipit bölgelerinde oluşan elektroporasyon, hücrenin ozmotik olarak şişmesi ve membranın zayıflayıp patlamasıyla sonuçlanmaktadır (Vega-Mercado ve ark., 1997; Lado ve Yousef, 2002). Elektroporasyona bağlı olarak hücrenin inaktivasyon mekanizması Şekil 2 'de gösterilmiştir.

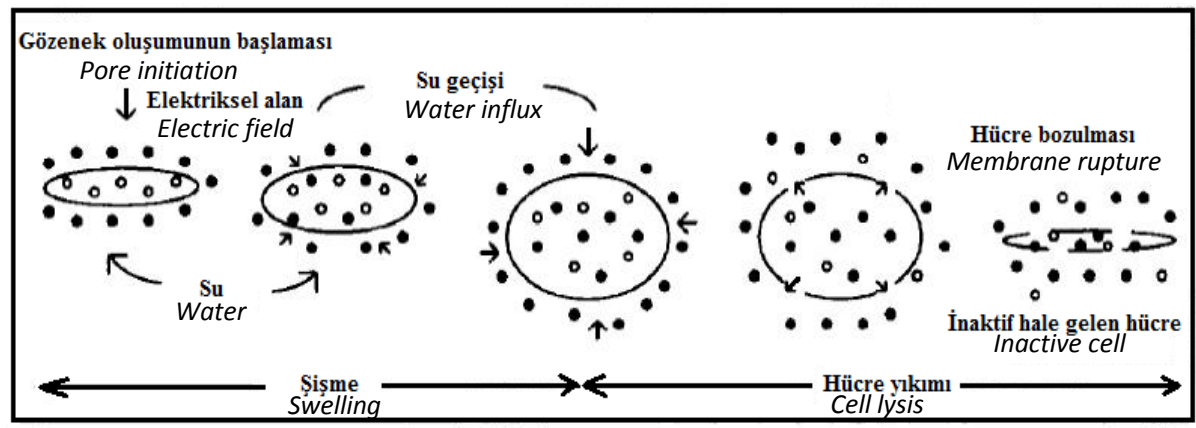

Şekil 2. Elektroporasyona bağlı hücre inaktivasyonu (Vega-Mercado ve ark., 1997)

Figure 2. Cell inactivation by electroporation (Vega-Mercado ve ark., 1997)

Ayrıca meyve sularında oldukça düşük elektrik alan şiddeti kullanılarak VEA işlemi uygulandığında, maya hücrelerinde öldürücü etkinin sağlandığı ve işlem sonrasında hücrelerde herhangi bir patlamanın meydana gelmediği belirlenmiştir. $\mathrm{Bu}$ durum öldürücü etkinin 
elektroporasyon olarak tanımlanan, VEA işlemi esnasında materyale uygulanan sinyallerin hücre zarında küçük gözeneklerin oluşmasına neden olarak küçük hücre bileşenlerinin dışarıya nüfuz etmesiyle sağlandığını ortaya koyan bir sonuçtur (Grahl ve Markl, 1996).

Inaktivasyon üzerinde etkili faktörler

Mikroorganizmalara ilişkin faktörler

Mikroorganizmanın tipi, gelişme evresi, büyüklüğü ve şekli inaktivasyon üzerinde belirleyici faktörlerdir (Wouters ve ark., 2001; Góngora-Nieto ve ark., 2002; Li ve Farid, 2016). Oda sıcaklığında veya öldürücü sıcaklık derecelerinin altında uygulanan birkaç mikrosaniyelik elektrik alan şiddetinin (20-50 kV $\mathrm{cm}^{-1}$ ) neredeyse tüm patojenler ve gıdalarda bozulma etmeni olan bakteriler üzerinde inaktivasyon etkisi yarattığı belirtilmiştir (Sharma ve ark., 2014; Impe ve ark., 2018). VEA etkisiyle olası membran hasarının tipi, boyutu ve hücre ölümü ile olan ilişkisinin hedef mikroorganizmanın türüne ve ortamın $\mathrm{pH}$ değerine bağlı olduğu açıklanmıştır (Garcia ve ark., 2005; Wan ve ark., 2009).

VEA işlemine karşı, genel olarak, maya hücrelerinin bakteri hücrelerinden, gram-negatif bakteri hücrelerinin de gram-pozitif bakteri hücrelerinden daha duyarlı olduğu (Toepfl ve ark., 2005; Wan ve ark., 2009), bakteri sporlarının inaktivasyonunda VEA işleminin yetersiz kaldığı çeşitli araştırmacılar tarafından belirtilmektedir (Góngora-Nieto ve ark., 2002; Lado ve Yousef, 2002; Toepfl ve ark., 2005; Wan ve ark., 2009; Timmermans ve ark., 2014; Impe ve ark., 2018). Benzer şekilde Grahl ve Markl (1996) tarafından VEA işleminde gönderilen elektrik alan sinyallerinin endosporlar ve askosporlar dahil tüm mikrobiyel sporların inaktivasyonu için yeterli olmadığı belirtilmiştir. Genel olarak, fungal askosporların vejetatif formlarına göre biraz daha dayanıklı oldukları ve bakteri sporları için belirtilen dirençlilik durumunun fungal askosporlar için pek telaffuz edilmediği söylenebilmektedir (Impe ve ark., 2018). Ancak bazı kaynaklarda vejetatif hücrelerin de VEA işlemine karşı direnç gösterebildiği bildirilmiştir. Staphylococcus aureus, E. coli ve Salmonella Typhimurium bakterilerinin devamlı olarak uygulanan VEA işlemini tolere edebildikleri (Zhao ve ark., 2013) ve bazı mikroorganizmaların klasik VEA işlemiyle tamamen inaktivasyonunun sağlanamadığı belirtilmektedir. Dolayısıyla VEA işlemine en dayanıklı bakteri olduğu bilinen Listeria monocytogenes'in inaktivasyonunun sağlanması VEA işleminin etkinliği açısından önemli olduğu düşünülmektedir (Saldana ve ark., 2009).

Gram-negatif bakterilerin VEA uygulamasına gram-pozitif bakterilerden daha duyarlı olmalarının, peptidoglikan tabakasında bulunan taykoik asitten ileri geldiği (Lado ve Yousef, 2002), hücre çapının VEA işlemiyle inaktivasyonda etkili bir faktör olduğu bildirilmiştir. Daha büyük çaplı maya hücrelerinin daha küçük çaplı tipik bakteri hücrelerine göre daha düşük elektrik alan şiddetinde inaktif hale geldiği belirlenmiştir (Grahl ve Markl, 1996).

Mikrobiyel inaktivasyon hızı ve düzeyini etkileyen diğer bir faktör, mikroorganizmanın fizyolojik durumudur. Gelişimlerinin logaritmik evresinde olan mikroorganizmaların VEA uygulamasına dayanımlarının yüksek olmadığı belirtilmiştir (Góngora-Nieto ve ark., 2002; Picart ve ark., 2002).

\section{Işlem parametreleri}

VEA ile mikrobiyel inaktivasyonda elektrik alan şiddeti, sinyal genişliği, sinyal şekli, sinyal sayısı (Wouters ve ark., 2001) ve işlem sıcaklığının (MacGregor ve ark., 2000) en önemli işlem parametreleri olduğu belirtilmiştir (Impe ve ark., 2018).

\section{Elektrik alan şiddeti}

VEA işlemi sırasında $5-50 \mathrm{kV} \mathrm{cm}^{-1}$ aralığında yüksek elektrik alan şiddeti uygulandığında mikrobiyel hücre membranlarında geri dönüşümsüz hücre ölümü sağlandığı (Timmermans ve ark., 2014) ancak elektrik alan şiddeti $15 \mathrm{kV} \mathrm{cm}^{-1}$ ve üzerinde iken mikrobiyel membranların tamamen parçalanmasına yol 
açmadığını belirtilmiştir (Gonzalez ve Barrett, 2010). Hücre membranları arasındaki potansiyelin artması kritik elektrik alan şiddetini $\left(E_{c}\right)$ arttırmaktadır. Elektrik alan şiddetinin membranlar arasındaki kritik potansiyelden daha yüksek olması durumunda mikrobiyel inaktivasyon düzeyi de artmaktadır. Kritik elektrik alan şiddetinden daha düşük değerlerde ise mikrobiyel inaktivasyon gerçekleşmemektedir. $E_{c}$ üzerinde ise sinyal genişliği ve hücre boyutu etkili olmakta, büyük hücrelerde membranlar arası potansiyelin daha fazla olduğu belirtilmektedir (Anonim, 2011b). Sinyal genişliği arttıkça $E_{c}^{\prime}$ nin azalması sonucu daha yüksek inaktivasyon sağlandığı ve $\mathrm{E}_{\mathrm{c}}$ değerinin, $50 \mu \mathrm{s}^{\prime}$ den yüksek sinyal genişliğinde, $4.9 \mathrm{kV} \mathrm{cm}^{-1}$ dolayında, $2 \mu \mathrm{s}^{\prime}$ den daha düşük sinyal genişliğinde ise $40 \mathrm{kV} \mathrm{cm}^{-1}$ civarında olduğu bildirilmektedir (Wan ve ark., 2009).

\section{İslem süresi ve sinyal geometrisi}

İşlem süresi, sinyal sayısının sinyal genişliği ile çarpımına eşittir. Bu değişkenlerden herhangi birindeki artış mikrobiyel inaktivasyonu da artırmaktadır. Sinyal genişliği, kritik elektrik alan şiddetini etkilemek suretiyle, mikrobiyel redüksiyonu etkilemektedir. Fakat sinyal genişliğindeki artış, üründe istenmeyen sıcaklık artışına neden olabildiğinden, işlem koşullarının en yüksek inaktivasyon hızında en az sıcaklık artışı olacak şekilde optimize edilmesi gerektiği de vurgulanmaktadır. Sinyal şekli ile polarite, mikrobiyel inaktivasyon üzerinde etkili diğer faktörlerdir (Wan ve ark., 2009). Elektrik alan sinyalleri üssel olarak azalan, kare-dalga, bipolar ya da salınımlı sinyaller şeklinde uygulanabilmektedir. Salınımlı sinyaller mikrobiyel inaktivasyonda en az etkili olan sinyal formudur. Uygulama sırasında toplam sinyal süresi boyunca, sürekli ve sabit yoğunlukta gönderilen kare-dalga sinyallerin, enerji tüketimi ve öldürücü etki açısından daha iyi sonuç vermesi nedeniyle, üssel olarak azalan sinyal formundan daha üstün olduğu düşünülmektedir (Wan ve ark., 2009; Anonim, 2011b). Ayrıca mikrobiyel inaktivasyonda bipolar (çift kutuplu) sinyallerin genel olarak monopolar (tek kutuplu) sinyallerden daha etkili olduğu da vurgulanmaktadır (Wan ve ark., 2009).

işlem sıcaklığı

İşlem sıcaklığı ile mikroorganizma inaktivasyonu arasında sinerjistik bir ilişki bulunmaktadır. Sabit elektrik alan şiddetinde, sıcaklık arttıkça mikrobiyel inaktivasyon artmaktadır. Bunun nedenleri, yüksek sıcaklık derecelerinde hücre zarının akışkanlığı ve geçirgenliğinde gözlenen değişime bağlı olarak hücrenin mekanik etkilere karşı daha duyarlı hale gelmesi (Anonim, 2011b) ile hücre zarında bulunan fosfolipidlerin akıcılığındaki artışın, membranda daha fazla gözenek oluşumuna neden olmasıdır (Wan ve ark., 2009). Aynı zamanda, ürün giriş sıcaklığı arttıkça VEA uygulaması için daha az enerjinin gerektiği ve VEA'nın etkinliğinin arttığı da belirtilmektedir (Siemer ve ark., 2014a).

\section{Ortam koşulları}

\section{Ürünün elektrik iletkenliği}

"Ortamın elektrik iletkenliği" ( $\sigma$, Siemens /uzunluk, S/m), elektrik akımını iletme yeteneği olarak tanımlanmaktadır. Elektrik iletkenliği yüksek olan gıdalar işlem haznesi içerisinde daha küçük elektrik alan pikleri oluşmasına neden olduğu için VEA işleminin etkinliği azalmaktadır (Anonim, 2011b; Siemer ve ark., 2014a). İşlem ortamının elektrik iletkenliği, VEA uygulaması sırasında, hedef mikroorganizma membranında oluşan potansiyeli etkilemektedir (Sepulveda ve ark., 2006; Noci ve ark., 2009). Aynı işlem koşullarında düşük iletkenliğe sahip sıvı gıdalarda yüksek düzeyde inaktivasyon sağlanmaktadır (Noci ve ark., 2009).

\section{Ortamın iyonik gücü}

İşlemin gerçekleştirildiği ortamda mevcut olan iyonlar VEA işleminin başarısını etkilemekte, mikroorganizmaların VEA işleminden zarar görmesini engelleyebilmektedir. íki değerli katyonların $\left(\mathrm{Mg}^{+2}, \mathrm{Ca}^{+2}\right)$ tek değerli katyonlar $\left(\mathrm{K}^{+}\right.$, $\mathrm{Na}^{+}$) ile eşleşmesinde membranı koruyucu bir etkinin ortaya çıktığı, dolayısıyla VEA işleminin öldürücü etkisinin azaldığı belirtilmektedir (Sun, 
2005). Yapılan bir çalışmada, uygulanan tamponda iki değerli katyonların $\left(\mathrm{Ca}^{+2}\right.$ ve $\left.\mathrm{Mg}^{+2}\right)$ bulunmasının E.coli'nin VEA uygulamasına direncini artırdığı gözlenmiştir (Wan ve ark., 2009).

\section{pH değeri}

pH'nın etkisi, hedef mikroorganizmaya göre değişiklik göstermektedir (Wan ve ark., 2009; Siemer ve ark., 2014a). Düşük pH değerlerinde E.coli, S.cerevisiae, Lactobacillus plantarum ve L.innocua VEA uygulamasına karşı daha fazla duyarlılık göstermektedir (Wan ve ark., 2009; Anonim, 2011b). Gram-negatif bakterilerin asidik ortamlarda VEA'ya karşı daha dirençli oldukları ve gram-pozitif bakterilerin ise nötral ortamlarda VEA'ya karşı daha fazla direnç gösterdikleri belirtilmiştir. Bununla birlikte, aynı mikroorganizmaların farklı suşlarının aynı $\mathrm{pH}^{\prime} \mathrm{da}$ VEA'ya karşı direncinin de farklı olduğu gözlenmiştir. Mikroorganizmaların inaktivasyonunda, VEA uygulamasının ve iyonik gücün elektroporasyon ile hücre büzülmesinden sorumlu olduğu, elektroporasyonun tamamlanmasından sonra ortam pH'sının sitoplazmayı etkilediği saptanmıştır (Siemer ve ark., 2014a).

\section{Ürün bileşimi}

Yağ ve protein gibi gıda bileşenlerinin, mikroorganizmaların inaktivasyonunda, koruyucu rol oynadıkları düşünülmektedir (Wan ve ark., 2009). Ortamdaki yağ içeriği arttıkça bakterilerin gönderilen elektrik alan sinyallerinden daha az etkilendikleri bildirilmiştir. Nitekim farklı yağ oranlarına sahip sütlerle yürütülen bir çalışmada, sütün yağ oranındaki artışla birlikte VEA etkisiyle E.coli'nin inaktivasyon düzeyinin azaldığı saptanmıştır (Grahl ve Markl, 1996). Ancak, $10^{7}$ kob $\mathrm{mL}^{-1}$ düzeyinde Listeria monocytogenes Scott A suşu inoküle edilen ve $30 \mathrm{kV} \mathrm{cm}^{-1}$ 'lik elektrik alan şiddeti uygulanan tam yağı, \%2 yağlı ve yağsız sütlerle yürütülen bir çalışmada, inaktivasyon düzeyi bakımından sütler arasında önemli bir farklılık bulunmadığı belirlenmiştir (Wan ve ark., 2009).
VEA uygulamasının gıda bileşenleri üzerindeki etkisi incelendiğinde ise; ısıya karşı duyarlı oldukları bilinen proteinlerin ve vitaminlerin belirli bir elektrik alan şiddetine kadar VEA işlemine karşı dayanım gösterdiği bilinmektedir. Sütte bulunan lipaz enzimi ve vitamin C için yüksek elektrik alan şiddetlerinde belirli bir düzeyde kayıp meydana geldiği bildirilmiştir. Alkali fosfataz, peroksidaz, vitamin $A$ ve serum proteinleri üzerinde ise VEA işlemi büyük boyutta bir değişim yaratmamıştır Süt ve portakal sularında VEA işleminin duyusal özellikler bakımından bozulmaya ilişkin herhangi bir olumsuzluk yaratmadığı belirtilmiştir. Bu sonuçlar klasik pastörizasyon ile muamele edilmesi güç olan, ısıya duyarlı gıda bileşenleri bulunan ortamlarda mikrobiyel bakteri yükünün azaltılmasında VEA işleminin uygun olabileceğini göstermektedir (Grahl ve Markl, 1996).

\section{Engeller teknolojisi}

Geleneksel koruma yöntemleri ile yenilikçi teknolojilerin birlikte kullanımı "engeller teknolojisi" olarak bilinmektedir (Cullen ve ark., 2012). Genel olarak, pH, sıcaklık, diğer fiziksel metotlar (Wang ve ark., 2018) ile antimikrobiyel bileşenlerin kullanımı (Nyugen ve Mittal, 2007; Pina-Perez ve ark., 2007; Wang ve ark., 2018) ve iyonik kuvvet gibi faktörlerin birlikte kullanılmasının VEA ile mikroorganizma inaktivasyonunun etkinliğini arttırdığı bilinmektedir (Devlieghere ve ark., 2004; Nyugen ve Mittal, 2007; Pina-Perez ve ark., 2007; Anonim, 2011b; Wang ve ark., 2018). Bunun nedeni olarak ise strese maruz kalmış hücrelerin VEA işlemine karşı daha duyarlı hale gelmeleri gösterilmektedir. Örneğin, VEA uygulamasında Lactococcus lactis subsp lactis tarafından üretilen bir bakteriyosin olan nisin ve hayvansal kaynaklı bir enzim olan lisozimin karışım halinde kullanımının etkisinin, nisin ve lisozimin yalnız kullanımında gözlenen etkiden daha yüksek olduğu saptanmıştır (Sun, 2005).

\section{VEA Teknolojisinin Uygulama Alanları}

Çeşitli meyve suları, meyve nektarları, süt ve yoğurt gibi ürünlerin duyusal ve besleyici 
niteliklerinde

değişim

yaratmaksızın

mikrobiyolojik açıdan güvenli hale getirilmesinde VEA işleminin ısıl işleme alternatif bir yaklaşım olduğu düşünülmektedir (Corbo ve ark., 2009). VEA uygulamasının birçok meyve suyunda mikrobiyel inaktivasyon etkisi incelenmiştir (Raso ve ark., 1998; Timmermans ve ark., 2014). VEA uygulamasının vişne, kayısı ve şeftali nektarlarında, Penicillium expansum üzerinde güçlü bir etki yarattığı belirlenmiştir (Elez Martinez ve ark., 2005; Evrendilek ve ark., 2008). Ayrıca VEA uygulaması ile işlenen gıdalarda Maillard reaksiyonunun kontrol altında tutulabildiği (Wang ve ark., 2013) gıdaların koagulasyon, köpük oluşturma ve emülsifikasyon özelliklerinde meydana gelen değişiklikler ile yeni ürün geliştirme potansiyeli sağlayan bir teknoloji olduğu bildirilmiştir (Cullen ve ark., 2012).

VEA tekniğinin süt ve süt ürünleri üzerine etkileri incelendiğinde, elektrik alan şiddeti ve sinyal sayısının işlemin başarısını belirlediği, sütün orijinal bileşimini, duyusal ve besleyici özelliklerini koruyan bir teknik olması nedeniyle süt endüstrisi alanında çalışmalar konu olmuş bir uygulama olduğu belirtilmiştir (Anlı ve Gürsel Kıral, 2013). Sütün VEA tekniği ile işlenmesi sırasında, serum proteinlerinde meydana gelen denatürasyon düzeyinin düşük olması immünolojik açıdan yararlı görülmektedir. Ancak, VEA işleminin, uygulanan doza bağlı olarak, sütün viskozitesi ve proteinlerin koagülasyon özellikleri üzerinde değişim yarattığı konusunda spekülasyonlar mevcuttur (Onwulata, 2008). Diğer taraftan, VEA tekniğinin olumsuz yönleri arasında bazı enzimlerin bu uygulamaya direnç göstermesi (Sun, 2005), bazı durumlarda enzimin başlangıçtaki aktivitesinde artış meydana gelmesi (Bendicho ve ark., 2002) ve enzim inaktivasyon düzeyinin artırılmasında mikrobiyel inaktivasyon için gereken enerjiden daha yüksek enerjiye ihtiyaç duyulması sayılabilir (CalderonMiranda ve ark., 1999; Bendicho ve ark., 2002; Onwulata, 2008).

Bununla birlikte, balık, et ya da diğer katı gıda maddelerinde mikrostrüktürel olarak istenmeyen etkiler göstermesi ve bakteri gelişimini etkin şekilde engelleyememesi nedeniyle, düşük şiddette elektrik alan sinyalleri kullanımının uygun olmadığı ifade edilmektedir. VEA uygulamalarının daha çok bitkisel materyallerden değerli bileşenlerin ekstraksiyonunda ya da bitkisel ve hayvansal organik materyallerin dehidrasyonunda tercih edilmesi gerektiği bildirilmektedir (Sun, 2005). Polistren ambalajlarda, biyofilm oluşturan E.coli'nin inaktivasyonu için VEA'nın kullanımının ilginç bir yaklaşım olduğu belirtilmiştir. Illetken olmayan yüzey olarak polistren boncuk kullanılarak bu yüzey üzerine bağlanan E.coli hücrelerinin; serbest yaşayan E.coli hücrelerine kıyasla VEA uygulamasına karşı daha duyarlı hale geldikleri ve bu şekilde bir bağlanmanın inaktivasyon hızını artırdığı belirlenmiştir (Dutreux ve ark., 2000). VEA teknolojisinin uygulama alanındaki üstünlükleri ve yetersizliklerine ilişkin hususlar Çizelge 1'de genel hatlarıyla özetlenmiştir.

Çizelge 1. VEA işleminin üstün yönleri ve yetersizlikleri (Devlieghere ve ark., 2004)

Table 1. Advantages and disadvantages of PEF technology (Devlieghere ve ark., 2004)

Üstün yönleri Yetersiz yönleri

Superior aspects Inadequate aspects

- İşlemin sürekli olması Continuous operation

- Besin değerinin yüksek oranda korunması

Highly protected nutritional value in processed foods

- Ürünün tazeye yakın, yüksek duyusal kaliteye sahip olması

Fresh-like, high sensorial quality in processed foods

- Asit karakterdeki gıdalara uygulanabilmesi Suitable for high-acid foods

- Sporların inaktivasyonu için diğer koruma teknikleri ile kombine edilebilmesi

Possibility of use together with other preservation techniques in spore inactivation
- Ekipman geliştirme çalışmalarının devam etmesi Continuing developments in equipment

- Yalnızca sıvı ürünlere uygulanabilmesi Suitable for use in only liquid foods

- Sporların direnç göstermesi Spore resistance against the technique

- Enzimlerin direnç göstermesi Enzymes resistance against the technique

- Etkinliğinin gıdanın elektrik iletkenliğine bağlı olması Degree of inactivation effect depends on electrical conductivity of food 


\section{VEA Teknolojisinin Yasal Yönleri}

Globalleşen gıda endüstrisi, ülkeler arasında uyumun sağlanması için kullanılan yeni gıda bileşenleri ve uygulanan yeni teknikleri de kapsayan uluslararası bazı standartlar oluşturulmasını gerekli kılmaktadır (Galic ve ark., 2010). Günümüz tüketicisinin gıda tercihlerinde söz konusu gıdanın duyusal özellikleri, sağlık üzerine etkileri, kolaylık, kalite, güvenilirlik, sürdürülebilirlik ve etik özellikleri belirleyici olmaktadır (Guimaraes ve ark., 2018). Yenilikçi teknolojiler, yüksek kalitede ürün üretilmesini amaçlayan ısıtma verimliliği ve enerji tasarrufu yüksek, çevre dostu olduğu düşünülen teknolojiler olarak bilinmektedir (Pereira ve Vicente, 2010). Yenilikçi teknolojiler olarak bilinen Isıl işleme alternatif yöntemler güvenli, besleyici ve daha iyi kalitede ürünler elde edilmesi için tasarlanmış olmasıyla birlikte bu yöntemlerin ısıl işlemler için de geçerli olan ve yasal otoriteler tarafından kabul gören birtakım gereklilikleri karşılamaları gerekmektedir (Wouters ve ark., 1999; Knorr ve ark., 2002). Bazıları endüstriyel kullanımda, pilot düzeyde veya kullanıma geçmek üzere olan yüksek basınç, vurgulu elektrik alan, süperkritik $\mathrm{CO}_{2}$, ultrasonik ses dalgalarının kullanımı, ozon ve plazma uygulamalarından günümüzde en başarılı ve birçok ticari uygulaması olanlar yüksek hidrostatik basınç ve vurgulu elektrik alan uygulamalarıdır (Castro ve ark., 2018). Ancak VEA tekniğinin ticari olarak uygulanabilirliğinin önünde yasal düzenlemelerin olmayışı engel olarak görünmektedir (Sepulveda ve ark., 2009). Isıl olmayan işlemlere tabi tutulan gıdalar, Amerika Birleşik Devletleri Gıda ve Ilaç Dairesi (FDA) tarafından belirlenen ve toplum sağlığının korunmasını güvence altına alan hükümlere uygunluk göstermeleri durumunda ticari olarak piyasada yer alabilmektedir (Góngora-Nieto ve ark., 2002; Corbo ve ark., 2009). Ayrıca Avrupa yenilikçi gıda mevzuatının toksin inaktivasyonu, alerjen maddelerin inaktivasyonu veya işlem sonrası oluşumu gibi konularda bazı gerekliliklerin sağlanması ısıl işleme alternatif yöntemlerin ticari olarak uygulanabilmesini düşünülmektedir (Knorr ve ark., 2002).

VEA uygulaması yönünden ekipman ve işlem dizaynı, ürün spesifikasyonları, işlemin doğrulanması, işlem sonucunda olabilecek besin kayıpları, toksik bileşiklerin oluşmasına yol açabilecek kimyasal değişimler, toksin üretimi ve proses kontrolü gibi konular önemli görülen hususlardır. $\mathrm{Bu}$ teknolojinin konuyla ilgili araştırmalara destek verecek uygun alt yapısı bulunduğu bilinmektedir (Góngora-Nieto ve ark., 2002; Corbo ve ark., 2009). Ancak bu teknik kullanılarak üretilen ürünlerin fonksiyonelliğinin in-vivo ve in-vitro ortamlarda incelenmesiyle, ayrıca toksikolojik olarak da test edilmesiyle ticarileşebilmesinin önündeki engelin ortadan kalkabileceği söylenebilir (Guimaraes ve ark., 2018).

Isıl işleme alternatif olarak geliştirilen bu yenilikçi teknolojiler için uygulandığı ülkeye bağı kalmaksızın güvenli bir şekilde kullanımını düzenleyici global bir yasal düzenleme sistemine ihtiyaç bulunmaktadır. FDA tarafından belirlenen spesifik konulara çözüm getirilmesi ve gıda güvenliği ile ilgili konuların her ülkenin kendi yasal organlarının gıda güvenliği ile ilgili konuları değerlendirmesi durumunda, VEA tekniğinin pastörizasyona alternatif bir yöntem olarak kullanılabileceği belirtilmektedir. Ayrıca global olarak oluşturulan bu sistemin çalışmalarını düzenleyen ve izleyen ve ülkeler arası farklılıkları engelleyici yönetim organlarına ihtiyaç bulunmaktadır (Castro ve ark., 2018).

\section{Sonuç}

VEA teknolojisi, sIVı gıdaların minimum düzeyde değişikle işlenmesine olanak tanıyan tat/aroma ve birçok fizikokimyasal özelliğin büyük ölçüde korunduğu mikrobiyel güvenliğin sağlanmasında kullanılabilecek olan yeni tekniklerden birisidir. Pastörizasyonla etkisi kıyaslandığında bu teknoloji ile tazeye yakın özellikte, yüksek kalitede ve aynı zamanda raf ömrü uzun gıdaların üretiminin sağlanabileceği belirlenmiştir. VEA teknolojiyle mikrobiyel güvenliğin yanı sıra gıdalarda bazı fonksiyonel 
özelliklerin geliştirilebileceği belirlenmiştir. Ancak teknolojinin gıda güvenliği kavramı ile uyumlu olarak kullanımı önem taşımaktadır. Aynı zamanda VEA teknolojisi, günümüzün ve geleceğimizin çevre ve insan sağlığı ile ilişkili en önemli konularından olan temiz çevrenin korunması ve yenilenemeyen kaynakların tasarruflu kullanımı konularında hassas olduğu bilinen teknolojilerden bir tanesidir. VEA teknolojisinin yatırım maliyetlerinin azaltılmasıyla, proses takibinin optimizasyonu ve yasal prosedürlerin yerine getirilmesiyle endüstriyel olarak yaygın olarak kullanımının sağlanabileceği düşünülmektedir.

\section{Kaynaklar}

Anlı, E. A., \& Gürsel Kıral, A. (2013). Vurgulu elektrik alan uygulamasının süt teknolojisinde kullanımı. Pulsed electric field application in dairy industry, Akademik Gıda Dergisi, 11(1), 64-68.

Anonim,(2011a).http://www.fshn.illinois.edu/food_processi ng_forum/.../c3_Barbosa_Abstract.pdf, Erişim tarihi 14.05.2011.

Anonim,(2011b).http://onlinelibrary.wiley.com/doi/10.1111 /j.17454565.2000.tb00619.x/pdf.Erişim tarihi 12.05.2011.

Aronsson, K., Ulf Rönner,U., \& Borch, E. (2005). Inactivation of Escherichia coli, Listeria innocua and Saccharomyces cerevisiae in relation to membrane permeabilization and subsequent leakage of intracellular compounds due to pulsed electric field processing. International Journal of Food Microbiology, 99, $19-32$.

Bendicho, S., Barbosa-Cánovas, G.V., \& Martín-Bellosa, O. (2002). Milk processing by high intensity pulsed electric fields. Trends in Food Science and Technology, 13, 195-204.

Buniowska, M., Carbonell-Capella, J.M., Frigola, A., \& Esteve, M.J. (2017). Bioaccessibility of bioactive compounds after non-thermal processing of an exotic fruit juice blend sweetened with Stevia rebaudiana. Food Chemistry, 221, 1834-1842.

Calderon-Miranda, ML, Barbosa-Canovas, GV, \& Swanson, BG. (1999). Inactivation of Listeria innocua in skim milk by pulsed electric fields and nisin. International Journal of Food Microbiology, 51, 19-30.

Castro, S.M., Inácio, R.S., Alexandre, E.M.C., Fidalgo, L.G., Pereira,S., Quaresma, P., Freitas, P., Teixeira, P., Pintado, M., Gomes, A.M., \& Tonello, C. (2018). Environmental Footprint of Emerging Technologies, Regulatory and Legislative Issues. In B. Francisco, A. de Souza Sant'Ana, V. Orlien \& M. Koubaa (Eds.), Innovative Technologies for Food Preservation Inactivation of Spoilage and Pathogenic Microorganisms (pp 255-276). USA: Academic Press.

Corbo, M.,R., Bevilacqua, A., Campaniello, D., D’Amato, D.,
Speranza, B., \& Sinigaglia, M. (2009). Prolonging microbial shelf life of foods through the use of natural compounds and non-thermal approaches- a review. International Journal of Food Science and Technology, 44, 223-241.

Cullen, P.J., Tiwari, B.K., \& Valdramidis, V.,P. (2012). Status and Trends of Novel Thermal and Non-Thermal Technologies for Fluid Foods. In B.K. Tiwari (Ed.), Novel Thermal and Non-Thermal Technologies for Fluid Foods (pp 1-6). UK: Food Science and Technology International Series, Academic Press is an imprint of Elsevier.

Devlieghere, F., Vermeiren, L., \& Debevere, J. (2004). New preservation technologies: Possibilities and limitations. International Dairy Journal, 14, 273-285.

Dutreux, N., Notermans, S., Wijtzes, T., Góngora-Nieto, M.M., Barbosa- Cánovas, GV, \& Swanson, B.G. (2000). Pulsed electric fields inactivation of attached and free-living Escherichia coli and Listeria innocua under several conditions. International Journal of Food Microbiology, 54, 91-98.

Elez-Martínez, P., Escolá -Hernández, J., Soliva-Fortuny, R.C., \& Martín-Bellosa, O. (2005). Inactivation of Lactobacillus brevis in orange juice by high-intensity pulsed electric fields. Food Microbiology, 22, 311319.

Evrendilek, G.A., Tok, F.M., \& Soylu, S. (2008). Inactivation of Penicillum expansum in sour cherry juice, peach and apricot nectars by pulsed electric fields. Food Microbiology, 25, 662-667.

Gabrić, D., Barba, F., Roohinejad, S., Gharibzahedi, S.M.T., Radojčin, M., Putnik, P., \& Kovačević, D.B. (2018). Pulsed electric fields as an alternative to thermal processing for preservation of nutritive and physicochemical properties of beverages: A review. Journal of Food Process Engineering, 41, e12638.

Galic, K. Scetar, M., \& Kurek, M. (2011). The benefits of processing and packaging. Trends in Food Science and Technology, 22 (2-3), 127-137.

Góngora-Nieto, M.M., Sepulveda, D.R., Pedrow, P., BarbosaCánovas, G.V., \& Swanson, B.G. (2002). Food Processing by Pulsed Electric Fields: Treatment Delivery, Inactivation Level, and Regulatory Aspects. LWT- Food Science and Technology, 35(5), 375-388.

González-Arenzana, L., Portu, J., López, R., López, N., Santamaría, P., Garde-Cerdán, T., \& López-Alfaro, I. (2015). Inactivation of wine-associated microbiota by continuous pulsed electric field treatments. Innovative Food Science and Emerging Technologies, 29, 187-192.

Gonzalez, M.E., \& Barrett, D.M. (2010). Thermal, high pressure, and electric field processing effects on plant cell membrane integrity and relevance to fruit and vegetable quality. Journal of Food Science, 75 (7), 121-130.

Grahl, T., \& Markl, H. (1996). Killing of microorganisms by pulsed electric fields. Applied Microbiology and Biotechnology, 45, 148-157.

Guimaraes, J.T., Silva, E.K., Freitas, M.Q., \& Cruz, M.A.A.G. (2018). Non-thermal emerging technologies and their effects on the functional properties of dairy products. Current Opinion in Food Science, 22, 6266. 
Impe, J.V., Smet, C., Tiwari, B., Greiner, R., Ojha, S., Stulić, V., Vukušić, T., \& Jambrak, A.R. (2018). State of the art of non -thermal and thermal processing for inactivation of microorganisms. Journal of Applied Microbiology, 125, 16-35.

Knorr, D., Ade-Omowaye, B.I.O., \& Heinz, V. 2002. Nutritional improvement of plant foods by nonthermal processing. Proceedings of the Nutrition Society, 61, 311-318.

Lado, B.H., \& Yousef, A.E. (2002). Alternative foodpreservation Technologies: efficacy and mechanisms. Microbes and Infections, 4, 433-430.

Li, X., \& Farid, M. (2016). A review on recent development in non-conventional food sterilization Technologies. Journal of Food Engineering, 182, 33-45.

MacGregor, S.J., Farish, O., Fouracre, R., Rowan,N.J., \& Anderson, J.G. (2000). Inactivation of pathogenic and spoilage microorganisms in a test liquid using pulsed electric fields. IEEE Transactions on Plasma Science, 28 (1), 144-149.

Nguyen, P., \& Mittal, G.S. (2007). Inactivation of naturally occurring microorganisms in tomato juice using pulsed electric field (PEF) with and without antimicrobials. Chemical Engineering and Processing: Process Intensification, 46, 360-365.

Onwulata C.I. (2008). Milk whey processes: Current and future trends. In C.I. Onwulata (Ed.), Whey processing functionality and health benefits (pp 369416). USA: Wiley-Blackwell Publishing.

Pan, Y., Sun, D., \& Han, Z. (2017). Applications of electromagnetic fields for nonthermal inactivation of microorganisms in foods: An overview. Trends in Food Science and Technology, 64, 13-22.

Pereira, R.N., \& Vicente, A.A. (2010). Environmental impact of novel thermal and non-thermal technologies in food processing. Food Research International 43, 1936-1943.

Picart, L., Dumay, E., \& Cheftel, C. (2002). Inactivation of Listeria innocua in dairy fluids by pulsed electric fields: influence of electric parameters and food composition. Innovative Food Science and Emerging Technologies, 3, 357-369.

Pina-Pérez, M.C., Rodrigo, D., Ferrer Bernat, C., Rodrigo Enguidanos, M., \& Martínez-López, A. (2007). Inactivation of Enterobacter sakazakii by pulsed electric field in buffered peptone water and infant formula milk. International Dairy Journal, 17, 14411449.

Qin, B. Barbosa- Cánovas, G.V., Swanson, B.G., Pedrow, P.D., \& Olsen, R.G. (1998). Inactivating microorganisms using a pulsed electric field continuous treatment system. IEEE Transactions on Industry Applications, 34 (1), 43-50.

Raso,J., Calderon', M.L., Gongora ',M., Barbosa-Canovas', G., \& Swanson, B.G. (1998). Inactivation of mold Ascospores and Conidiospores suspended in fruit juices by pulsed electric fields. LWT- Food Science and Technology, 31(7-8), 668-672.

Schilling, S., Alber, T., Toepfl, S., Neidhar, S., Knorr, D., Schieber, A., \& Carle, R. (2007). Effects of pulsed electric field treatment of apple mash on juice yield and quality attributes of apple juices. Innovative
Food Science and Emerging Technologies, 8, 127134.

Sun, D. (2005). Emerging Technologies for Food Processing. USA: Food Science and Technology International Series Elsevier Academic Press.

Sepulveda, D. R., Guerrero, J. A., \& Barbosa-Canovas, G. V. (2006). Influence of electric current density on the bactericidal effectiveness of pulsed electric field treatments. Journal of Food Engineering, 76(4), 656663.

Sharma, P., Oey, I., Bremer, P., \& Everett, D.W. (2014). Reduction of bacterial counts and inactivation of enzymes in bovine whole milk using pulsed electric fields. International Dairy Journal, 39 (1), 146-156.

Siemer, C., Toepfl, S., \& Heinz, V. (2014a). Inactivation of Bacillus subtilis spores by pulsed electric fields (PEF) in combination with thermal energy I. Influence of process- and product parameters. Food Control 39, 163-171.

Siemer, C., Toepfl, S., \& Heinz, V. (2014b). Inactivation of Bacillus subtilis spores by pulsed electric fields (PEF) incombination with thermal energy II. Modeling thermal inactivation of $\mathrm{B}$. subtilis spores during PEF processing in combination with thermal energy. Food Control, 39, 244-250.

Timmermans R.A.H., NieropGroot, M.N., Nederhoff, A.L., van Boekel, M.A.J.S., Matser, A.M., \& Mastwijk, H.C. (2014). Pulsed electric field processing of different fruit juices: Impact of $\mathrm{pH}$ and temperature on inactivation of spoilage and pathogenic microorganisms. International Journal of Food Microbiology, 173, 105-111.

Toepfl, S., Heinz, V., \& Knorr, D. (2005). Overview of pulsed electric field processing for food. In D. Sun (Ed.), Emerging Technologies for Food Processing, Food Science and Technology International Series (pp 6997). USA: Elsevier Academic Press.

Vega-Mercado, H., Martín-Bellosa, O., Qin, B., Chang, F.J., Góngora-Nieto, M.M., Barbosa-Cánovas, G.V., \& Swanson, B.G. (1997). Non-thermal food preservation: Pulsed electric fields. Trends in Food Science and Technology, 8 (5), 151-157.

Wan, J., Coventry, J., Swiergon, P., Sanguansri, P., \& Versteeg, C. (2009). Advances in innovative processing technologies for microbial inactivation and enhancement of food safety - pulsed electric field and low temperature plasma. Trends in Food Science and Technology, 20, 414-424.

Wang, Z., Wang, J., Guo, S., Ma, S., \& Yu, S. (2013). Kinetic modeling of maillard reaction system subjected to pulsed electric field. Innovative Food Science and Emerging Technologies, 20, 121-125.

Wouters, P.C., Dutreux, N., Smelt, J.P.P.M., \& Lelieveld, L.M. (1999). Effects of pulsed electric fields on inactivation kinetics of Listeria innocua. Applied and Environmental Microbiology, 65 (12), 5364-5371.

Wouters, R.C., Alvarez, I., \& Raso, J. (2001). Critical factors determining inactivation kinetics by pulsed electric field food processing. Trends in Food Science and Technology, 12, 112-121. 